\title{
Institutional impacts on corporate social responsibility: a comparative analysis of New Zealand and Pakistan
}

\author{
Majid Khan*, James C. Lockhart and Ralph J. Bathurst
}

\begin{abstract}
This study explores the relationship between institutional mechanisms and corporate social responsibility (CSR) in both Pakistan and New Zealand. Institutional factors are normally categorised as being either formal or informal. It is argued that a combination of formal institutions and informal institutions in any jurisdiction shape the adoption, or otherwise of CSR by business through its adherence to acceptable governance praxis. Corporate regulation in Pakistan is heavily influenced from elsewhere, especially from British common law. By contrast the institutional realities produce remarkably different outcomes in the two jurisdictions. This study examines which formal and informal institutions influence CSR disclosures, in that businesses disclose CSR practices in response to regulations; cognitive pressures that help people understand and interpret the practice correctly; and, cultural values enforcing the same practice. Quantitative content analyses of a sample of eight listed companies' annual reports were completed from each country. Reporting and disclosure practices were identified in both. Underlying institutions were then recorded as being recognised, acknowledged or inferred by the respective reporting business. The results highlighted that Pakistani companies disclose more about CSR than those analysed from New Zealand. This result is attributed to the recently developed corporate governance guidelines by the Securities and Exchange Commission of Pakistan. The informal national institutions in both countries also play a vital role in the disparity of disclosures. This is not to suggest that New Zealand listed companies lag behind those in Pakistan with respect to their contribution to CSR initiatives, simply that the disclosure levels between the two favour those companies in Pakistan.
\end{abstract}

Keywords: Corporate social responsibility, Corporate governance, Regulation, Institutional theory, New Zealand, Pakistan

\section{Introduction}

To be accountable to stakeholders and society at large, businesses have increased the issuance of corporate social responsibility reports explaining the impact of their activities on the environment and the use of natural resources (Garcia-Sanchez et al. 2016). Earlier studies have explored the relationship between CSR and subsequent financial performance (Cochran and Wood 1984; Jitaree 2015; Sweeney 2009) or business attributes, such as size (Udayasankar 2008), business risk (Jo and Na 2012), and industry membership (Hull and Rothenberg 2008). In their landmark meta-analysis of CSR studies from 1972 to 2002, Margolis and Walsh (2003) argued that in only about 15\% of studies CSR was taken as a dependent variable. However, according to Luo and Bhattacharya (2009) the question of the merits

\footnotetext{
* Correspondence: m.khan@massey.ac.nz

Massey Business School, Massey University, Palmerston North, New Zealand
}

of CSR still lingers. Attention needs to be directed to the institutional mechanisms that result in the implementation of CSR (Doh and Guay 2006). Business response to accountability pressures from stakeholders is becoming even more convoluted. These pressures have been identified as being either coercive, normative, or mimetic. In responding to these pressures reporting on environmental, social, community and corporate governance has emerged as an important criterion for investment decision making (Eccles and Krzus 2010). However, disclosing CSR outcomes through various reports remains far from consistent, especially in the developing world.

Despite the vast literature on CSR, meanings, application and interpretation appears to differ from one context to another (Kang and Moon 2011). De Bakker et al. (2005) identified relations between CSR and the broader literature on comparative capitalism and set the tone for 
comparative institutional research on CSR (as cited in Jackson and Apostolakou 2010; Matten and Moon 2008). For example, they posed the now famous question asking why CSR is an implicit element of the institutional framework of corporations in Europe, whereas it is an explicit element of corporate policies in the United States of America. Much of the research on CSR has been conducted in the developed world (North America \& Europe) but interest is now growing in larger emerging countries (Aguinis and Glavas 2012; Karam and Jamali 2017). In addition, there is a clear scarcity on how CSR is understood, practiced and evaluated across different cultures (Diehl et al. 2016; Fifka 2013; Matten and Moon 2008). Therefore, we lack understanding of different national interests, viewpoints and identities. In other words, there is a paucity of understanding on how the responsibilities of companies and various actors are constructed in different institutional and national settings. In order to address this deficiency this study compares the CSR disclosure practices of a sample of listed companies in New Zealand with a comparable sample in Pakistan.

The regulatory environment in New Zealand does not prescribe social and environmental disclosure (Dobbs and van Staden 2016). Neither the Companies Act, 1993 nor the Financial Reporting Act, 1993 requires companies to include CSR-related information in their annual reports. Furthermore, there is no mention of CSR disclosures in corporate governance principles of either the New Zealand Stock Exchange or Securities Commission New Zealand. Blackmore (2006) argued that traditionally New Zealand's approach in reforming corporate governance has been led by the Financial Market Authority (FMA). New Zealand is not the only country that does not prescribe CSR disclosure. For example, in a comparative analysis of corporate governance in New Zealand, Australia and the United States of America Blackmore (2006) observed that they have contended that these countries have near analogous capital markets and company law. Given that New Zealand and Pakistan also have near identical regulations, their foundations both being from British common law, the aim of this study is to conduct a comparative analysis of regulatory and institutional mechanisms that shape CSR disclosures in each jurisdiction.

Following the developed world, the Securities and Exchange Commission of Pakistan (SECP hereafter) introduced voluntary guidelines for corporate social responsibility practice and disclosure (Securities and Exchange Commission of Pakistan 2013). The CSR guidelines are provided in order to integrate decisions and operations of the business with responsible practices. As recently as November, 2017, the SECP issued the listed companies (Code of Corporate Governance Regulation, 2017) and provided additional policies regarding CSR. The regulation focuses on social, environmental and governance in addition to aligning health and safety aspects in business strategies that promotes sustainability. "This includes but is not limited to corporate social responsibility initiatives and other philanthropic activities, donations contributions to charities and other social causes" (Securities and Exchange Commission of Pakistan 2017, p. 5). The 2017 code requires the $\mathrm{CEO}$ of listed companies to publicly identify issues, such as the implementation of environmental, social, health, and safety practices for decisions by the company's board of directors. However, due to the distortions in the economy market forces in Pakistan do not yet appear to punish unethical practices or reward good governance (Tahir et al. 2012), despite the development of the code and respective CSR guidelines. For example, the promotion of transparency and accountability in business is effectively discouraged due to the relatively large size of the undocumented economy. Previous studies have highlighted that there is weak corporate governance and infraction in Pakistan, however, the actual literature on CSR disclosures in Pakistan is scant. A small number of studies have focussed on CSR disclosures and there is a call for academic inquiry into the matter in developing countries (Ahmed Haji 2013; Belal and Momin 2009; Javaid Lone et al. 2016). This study therefore, contributes to the disclosures literature by explaining the difference of CSR discloses between a developing and a developed country. The study explores the institutional settings under which the regulatory and informal institutional environment have an influence on corporate social responsibility.

\section{Corporate social responsibility disclosures}

Margolis and Walsh (2003) observed that businesses are increasingly considered to resolve societal problems. This is because organisations are facing numerous pressures from stakeholders in the contemporary business environment. Corporate social responsibility is an umbrella term for the relationship between business and society. Baumann-Pauly et al. (2013) defined CSR as integration of environmental, social and ethical considerations into business conduct, often in line with the interests of stakeholders. The definition suggests that businesses not only operate for efficiency but also include accountability to stakeholders. CSR can then be used as a means of communication to a particular group of stakeholders by the businesses (Jitaree 2015). One of the key tools for communicating information to company stakeholders is through CSR reporting (Ahmed Haji 2013; Fifka 2013; Golob and Bartlett 2007; Xiaowei Rose et al. 2017). Various reasons behind CSR disclosures include, but are not limited to enhancing financial performance (Platonova et al. 2016; Qiu et al. 2016); strengthening company reputation (Birkey et al., 2016; Unerman 2008); compliance with regulation (Birkey et al., 2016); and, to gain legitimacy (Bachmann and Ingenhoff 2016; Chauvey et al. 2015). 
Businesses use CSR reporting as a tool to inform different stakeholders about environmental, social and other related issues. The "public information model" explains the basic form of CSR reporting (Grunig 1989, p. 22). This model should provide information "to the public on what the organization has done to be responsible and should explain lapses into irresponsibility" (Grunig 1989, p. 48). Businesses then appear to use these reports as a tool through which to legitimise their activities (Hooghiemstra 2000). These reports can be mandatory or discretionary (van der Laan 2009). Those defending mandatory disclosures argue that disclosures should be regulated by the state and to get accurate information and to protect a nation's citizens (Doane 2002). However, disclosures are only slowly gaining advocacy and largely remain in an underdeveloped form. At the heart of voluntary disclosure is the demand for information by a specific group of stakeholders (van der Laan 2009). Van der Laan (2009) further argued that voluntary disclosure might involve a separate disclosures section, such as, stand-alone social sustainability or environmental disclosure or involve various management discussions and explanations.

Lenssen et al. (2011) argued that the response of business to social pressure results in prestige and social acceptance. Accordingly, many countries have issued guidelines regarding CSR disclosures and good governance, for instance, the Combined Code in the United Kingdom; the OECD guidelines; the German Code; the Austrian Code; and, the Second King Report in South Africa. These recommendations and guidelines are attributed to have had a spectacular influence on the socially responsible behavior of businesss (Spitzeck 2009).

The idea that institutional pressures influence CSR disclosures is central to the current study. By focussing on two different institutional settings, the study looks to further unpack the different formal and informal institutional pressures that help to understand the reason behind disclosures. The CSR reporting issue is becoming more prevalent not only at national level but globally (Golob and Bartlett 2007; Tschopp and Huefner 2015). Research on CSR disclosures is dated from the late 1980s. Since then there has been a dramatic increase in research inquiries on the subject (see Hackston and Milne 1996). Most inquiries have focused on environmental disclosures rather than emerging social issues (Parker 2014). Additionally, the majority of the disclosure studies have been based in developed world and developing countries have received little attention (Fifka 2013) to date.

\section{CSR reporting in Pakistan}

One of the oldest civilisations in the world is in the Indus Valley (South Asia), dating back 5000 years, and now spread over what is today Pakistan. Pakistan is the 6th most populated country in the world with a population of approximately 200 million (Warriach 2017), with a total land area of 796,095 sq. km. As of 2017, Pakistan remains an economically weak country with a purchasing power parity (PPP) per capita of US\$5100.

When it comes to research on CSR, South Asia has been the recipient of less attention than East Asia. Furthermore, CSR studies in South Asia are predominantly focussed on Bangladesh and India. Pakistan has received less attention from CSR studies in general and disclosure studies in particular (Ahmad 2006; Hassan et al. 2012). To date, the concept of CSR in Pakistan has largely been limited to discussions in the media (Waheed 2005), despite corporate governance reforms for listed companies by the SECP (Javid and Iqbal 2010). While it is commonly argued that Pakistani companies lag behind in CSR initiatives there companies that appear to be taking CSR seriously and actively contributing to society (Shahid 2012). The CSR practices of Pakistani companies are primarily oriented towards philanthropy (Ahmad 2006). Jabeen and Khan (2008) contended that culture, religion and family traditions are the factors that compel both organisations and society to involve in charitable activity. The bulk of such donations go to the health and education sectors. Additionally, companies have started to engage in broader environmental, community and social issues. However, in an age of growing CSR and global awareness, corporate scandals exist in Pakistan commonly in the shape of exploitation of workers (Ashraf 2018), child labour (Delaney et al. 2016), and other corporate abuses. Multinational companies in Pakistan are now taking the lead in the implementation of CSR and have specialised departments to design and and publish on the role of their businesses in society in annual reports or one off sustainibility reports. Raza and Majid (2016) argued that SMEs are largely unware of the idea of being socially responsible, however, some improvement has been noted. CSR activities in Pakistan, while prescribed are voluntary with respect to disclosure of corporate, labour, environment, and consumers protection. According to Ahmed and Ahmed (2011) there is a lack of uniform laws compelling businesses to consider CSR and few industires have developed ethical principles and codes of conduct. There is, however, a general perception among businesses that CSR relates to philanthropy (Saj)ad and Eweje 2014), and that CSR is not linked to the creation of shared value. As the majority of the population in Paksitan lives in rural areas (approximately 70\%), CSR has the potential of creating diffrences in rural development, health care, community empowerment, education, awareness about rights and duties, perception of laws, entrepreneurship opportunities, ensuring transperancy, development of insfrastructure and enhancing business performance (Ahmed and Ahmed 2011).

Following these global traditions, voluntary guidelines for CSR have been issued by the SECP (SECP 2013). Javaid 
Lone et al. (2016) noted that that these guidelines are directed at business in Pakistan with the aim to better motivate them towards socially responsible conduct. Furthermore, the guidelines recommend that businesses have a CSR policy incorporated by their board, reflected in the form of their commitment to reporting CSR-related activities. The SECP is now playing a pivotal role in promoting a culture of socially responsible business (Ahmad et al. 2015) because the presence of independent monitoring organisations and state regulation are likely to stimulate CSR-related activities (Campbell 2007). For example, Ahmed Haji (2013) argued that the initiation of the Silver Book for Malaysian publicly owned companies resulted in a drastic increase in CSR disclosure in that jurisdiction. Similarly, Javaid Lone et al. (2016) observed that companies disclosed more CSR related activities in Pakistan following the introduction of CSR guidelines. But the extent of these disclosures appears to vary considerably across industrial sectors.

\section{CSR reporting in new Zealand}

New Zealand is a geographically isolated developed country located in the South Pacific Ocean, its closest neighbour of significance being Australia (it is $2161 \mathrm{~km}$ from Sydney to Auckland). New Zealand is a small country, similar in size to either Great Britain and Japan, with a small population of 4.5 million. It has a fascinating history reflecting a unique mix of European and Maori culture. New Zealand has an open market that works on freemarket principles. It is considered one of the most deregulated economies amongst the OECD (Kelsey 1995; Frame et al. 2003). Major exports include tourism, dairy products, logs and timber, lamb and beef.

Roper (2004) argued that the political, social and economic history of New Zealand has significant effect on its response to social responsibility and sustainability issues. As recently as the 1990s CSR was not publicly considered (Roper 2004). CSR is still not a dominating phenomenon in New Zealand, however, it is now growing rapidly in the contemporary business environment (Eweje and Bentley 2006). Recently, major CSR practices in New Zealand have been centred around environment and social issues among others. Collins et al. (2010) argued that businesses in New Zealand are more engaged in social practices than environmental sustainability practices. The most common social issue tackled was found to be provision of employees for time and money for charity, while the most common environmental-oriented practice was recycling by companies (Fernando 2013).

Environmental and social disclosure is not legislated within the current New Zealand reporting system (Dobbs and van Staden 2016). The Companies Act 1993 does not require companies to include information about corporate social responsibility in their annual reports nor does the
Financial Reporting Act 1993 require the reporting of environmental and social activities (Hofstede et al. 2010; Ministry of Business Innovation and Employment 1993, p. 105). In addition, the New Zealand Stock Exchange (NZSE) has no requirement for CSR discloses by listed companies (Dobbs and van Staden 2016). Furthermore, neither the corporate governance principles of the Financial Market Authority nor the NZSE specifically covers CSR, although the principles implicitly embrace the concept of CSR. Reporting of CSR is, therefore, entirely voluntary in New Zealand. Many other countries that also make no specific CSR disclosures mandatory (Dobbs and van Staden 2016).

Businesses in New Zealand are observed to provide very few reports regarding specific social and environmental disclosures (Reddy et al. 2010). The KPMG survey of international CSR reporting identified only 27 of the top 100 listed companies in New Zealand disclosing information regarding CSR activity (Dobbs and van Staden 2016). The scarcity of consistent guidelines or regulations regarding the quality and structure of CSR disclosures have led those companies that do report on social and environmental activities to use a wide variety of tools, techniques and disclosures (Reddy et al. 2010). So while reporting is not mandated various tools and measures are being employed and reported upon in a manner anticipated by a free market.

\section{Theoretical framework: Institutional theory}

According to Berger and Luckmann (1966) institutions refer to a certain exemplification where under a certain situation $\mathrm{X}$, an actor $\mathrm{Y}$, is expected to do Z. Alternatively, institutions are considered to be a habitual pattern of behavior which further enables or constrains people. Streeck and Thelen (2005) contended that a specific way of doing things can be considered as institutionalised within a context to the extent that subsequent deviant behavior will result in loss of legitimacy, and likely result in social sanctions. According to Brammer et al. (2012), this applies to both the formal and informal instructions in society. New institutional theory encompasses normative regulative and mimetic dimensions explaining why organisations become isomorphic within an organisational field over time (DiMaggio and Powell 1983). Therefore, one of the most important dimensions of institutional theory is isomorphism. The process of isomorphism refers to similarities or homogenisation (DiMaggio and Powell 1983). In line with this, they defined isomorphism as the forces that enable or constrain one organisation in an organisational field to resemble other organisations facing similar prevailing institutional conditions. Isomorphism can further be categorised into two components, institutional isomorphism on the one hand and competitive isomorphism on the other (Moll et al. 2006). Competitive isomorphism refers 
to "how competitive forces drive organizations towards adopting least-cost, efficient structures, and practices" (Moll et al. 2006, p. 187). Whereas according to DiMaggio and Powell (1983), institutional isomorphism was further broken down into three sub- categories, coercive isomorphism, normative isomorphism, and mimetic isomorphism. Each of the three sub-categories of institutional isomorphism are now discussed.

Coercive isomorphism relates to external factors, such as government regulations and shareholders' and employees' influence. Such pressures arise because of powerful actors, such as government regulation or industry self-regulation to change organisational institutional practices, for example, CSR (Deegan and Unerman 2009). Because of the sector-wide impacts of coercive isomorphic organisational responses have a tendency to converge over time.

The second type of isomorphism is mimetic. Mimetic isomorphism occurs when organisations trying to copy or emulate the practices of other organisations to gain a competitive advantage in the form of legitimacy. DiMaggio and Powell (1983) discovered that one of the powerful factors that emerge with mimetic isomorphism is uncertainty. Organisations will risk legitimacy if they fail to follow procedures adopted by other organisations or adopt innovative practices within the same institutional field (Unerman and Bennett 2004). Therefore, organisations adopt CSR practices in order to enhance and maintain their legitimacy, especially legitimacy relative to their competitors.

The last type of isomorphism is normative isomorphism which emerges from the common values underpinning specific institutional practices. Deegan and Unerman (2009) contended that a form of normative isomorphism occurs when there is a professional expectation, such as that to which accountants comply with accounting standards while producing accounting reports. Similarly, a voluntary CSR initiative may also be considered a form of normative isomorphism as it is increasingly adopted over time.

Irrespective of organisational efficiency or actual usefulness of the specific isomorphism, these processes lead organisations to adopt similar management practices and structures within their industry over time (Carpenter and Feroz 2001). In line with this, Carpenter and Feroz (2001) argued that organisations will respond to pressures from the institutional environment adopting the various forms that are regarded appropriate. Therefore, institutional theory locates corporate social responsibility within a broad area of economic governance comprising various modes, such as state regulation, the market, and beyond (Brammer et al. 2012). Institutional theory provides an important and powerful oversight from which to understand the attitudes and practices in a specific context (DiMaggio and Powell 1991). Kang and Moon (2011) argued that the institutional context of an individual country determines what business conducts means to those organisations operating in that context. From this position Matten and Moon (2008) in their landmark contribution on implicit and explicit CSR illustrated the difference between the United States of America and Europe, where CSR was found to be an implicit element of the institutional framework of corporations in the Europe but an explicit element of corporate policies in America.

Brammer et al. (2012) argued that research adopting the lens of institutional theory to explain business responsibilities has been focused on the diversity of CSR and the dynamics of CSR. Their observation concurs with the two conspicuous schools of thought in institutional theory:

"New institutionalists tend to emphasize the global diffusion of practices and the adoption of these by organizations, but pay little attention to how such practices are interpreted or 'translated' as they travel around the world [...]. The business systems approach highlights how business continues to be influenced by the national institutional frameworks in which it is embedded, but tends to play down the effects of transnational developments on national patterns of economic organization". (Tempel and Walgenbach 2007, p. 2)

The diversity perspective in institutional theory has been employed in CSR research to explain cross-national differences in CSR practices (Gjølberg 2009; Jackson and Apostolakou 2010). A comparative view on CSR helps understand the country specific meanings of CSR as a management function. CSR as a US concept (Carroll 2008), can hardly be understood without understanding the institutional environment under which the idea was considered. In line with this, Doh and Guay (2006) argued that the institutional framework of businesses in a particular country determines what it means to be socially responsible. This institutional environment is not only limited to the formal institutions, such as laws, trade unions and civil society among others but also involves the informal institutions, such as religious norms, culture, tribal traditions or customary norms (Brammer et al. 2012). However, these analyses have rarely transcended to the comparison of responsibility practices in developing countries with that of developed countries.

In addition to diversity, the dynamics of the concept and its applications have changed and research in the area has recently gained momentum. Dynamics refers to the ways in which CSR has diffused from Western systems of capitalism to other countries through imitation and adaptation (Brammer et al. 2012). The formidable lens of institutional theory appears to help understanding how and why CSR has different forms in different contexts. In addition, to the country-specific understanding of 
CSR, institutional theory also helps explain why the concept is now an integral to businesses in almost every country in the world (Visser and Tolhurst 2010).

\section{Corporate regulation}

The corporate regulation landscape comprises various a range of regulatory systems. The prominent systems amongst these are statutory regulation, co-regulation, and self-regulation. Statutory regulation refers to necessary rules, monitoring compliance and enforcement of these actions by imposing sanctions (Rahim 2013). Palzer and Scheuer (2003, p. 27) noted that the implementation of these rules is the responsibility of government. By contrast, Black (1996, p. 27) defined self-regulation as "the situation of a group of persons or bodies, acting together, performing a regulatory function in respect of themselves and others who accept their authority". With selfregulation, private parties, such as the industries, the business itself, providers, and producers among others take responsibility for implementation. In the case of selfregulation governments do not normally interfere and private parties monitor compliance (Rahim 2013). In line with this, Palzer and Scheuer (2003) highlighted that selfregulation may take the form of qualitative or technical standards potentially associated with a code of conduct describing what is good and bad practice. These codes may involve rules on the structure of the relevant complaints bodies and on out-of-court mediation. Finally, coregulation has been defined as an intermediate interaction between government and businesses (Palzer and Scheuer 2003). A co-regulatory system combines the elements of both self-regulation and statutory regulation (Nakpodia et al. 2016). Depending on the actual combination of statutory regulation and self-regulation elements, co-regulation can take different forms of regulatory strategy (Rahim 2013). Government lays down the legal basis to start the functioning of the system, businesses then formulate rules which depict its functioning (Rahim 2013). All these types of regulations have different effects on the CSR practices, especially listed companies that are required to maintain regular disclosures of performance.

Issues understanding the relationship between state regulation and self-regulation have emerged. According to Baldwin (2004), the rise of the modern regulatory state occurred in the second half of the twentieth Century in the United Kingdom following a noted increase in punitive regulation and the subsequent decline in traditional forms of self-regulation. However, this trend has not been the only way for regulatory change to emerge. Hutter (2001) argued that in some areas there has been a move towards self-regulation in areas, such as health and safety. By contrast, in areas, such as a wide range of industrial, economic, financial, legal, health, culture, education and sports state regulation is increasingly evident (Bartle and
Vass 2007). Therefore, there is now an on-going debate as to whether self-regulation or state regulation is the best governance mechanism for CSR practices.

\section{Methods \\ Sampling and data}

The objective of this study is to determine and contrast the regulatory and institutional impacts on corporate social responsibility within New Zealand and Pakistan. This section describes the measurement, sampling and research design used.

Annual reports of selected companies were used to analyse the association of institutional factors (formal \& informal) and CSR. The data was collected from a select sample of listed companies on each of the New Zealand Stock Exchange (NZX) and Pakistan Stock Exchange (PSX). The reason for evaluating the reports for one year was to determine a status quo of CSR disclosures in both countries. The sample was limited to eight companies from each exchange. Companies from New Zealand were selected across a broad range of industries and sectors: Air New Zealand, Freightways, Michael Hill International, Cavalier Corporation, Fletcher Building, Restaurant Brands, Spark (formerly Telecom), and Steel \& Tube Holdings. Similarly, a wide range of companies from Pakistan were chosen - Pakistan International Airline, Pakistan Telecommunication Company Limited, Aisha Steel Mills Limited, Millat Tractors, Engro Fertilisers, Nestle Pakistan, Gul Ahmed Textile Mills Limited and Fauji Cement. The study only used the annual report as the sampling unit. Annual reports have been previously accepted as an appropriate source of business' attitude towards social and environmental reporting (Campbell 2000). Additionally, as the study is primarily focussed on a small number of companies, representing a wide range of industries, care needs to be taken in extrapolating to the wider population. These companies were chosen because they are major players in their respective industries in each country. The study covered the companies' annual reports for the year 2016.

\section{Measurement \\ Dependent variable}

The study used a quantitative content analysis method. The content analysis was then done in two stages. A CSR checklist was constructed in the first stage. The categorisation was based on earlier studies (Aras et al. 2010) each of which identified location; broad themes of disclosures; and, the form of CSR in annual reports. Location involved corporate governance section, operation review section, chairman's report section and CSR section. Themes of disclosure were based on environment-related activities, employee-related activities, energy, product responsibility and community involvement. The form of the disclosures involved narrative, photographs and monetary data related 
to each of the themes. The CSR checklist was then developed and pre-tested to create an index of the dependent variable. The index was treated as a dichotomous variable, that is, if the company disclosed the specific CSR item it took the value ' 1 ' if no disclosures, it took ' 0 '. Items were included about each of the mentioned themes and scores were aggregated from these items related to CSR.

Various methods have been employed by researchers for quantitative content analysis of CSR in listed company annual reports, such as counting the number of words (e.g. Haniffa and Cooke 2005; Zeghal and Ahmed 1990), counting the number of sentences, (e.g. Aras et al. 2010; Milne and Adler 1999; Nazli Nik Ahmad and Sulaiman 2004) and counting paragraphs and the proportion of pages (Gray et al. 1995; Tilt 2001) committed to CSR. This study utilised phrase level analysis as data. The disadvantages associated with word counts is that they give no meaning to the context. Similarly, one of the criticisms of page proportions is that it disregards the difference in page margin, font size, and numbers of photos and graphics in annual reports. Moreover, the reports of companies vary in quality and format. The CSR index was calculated using guidelines from previous studies (e.g. Jitaree 2015). CSR was divided CSR into 45 items (broadly classified into 11 items for environmental dimensions, six energy dimensions, 16 employee dimensions, seven community involvement dimensions, and five product responsibility dimensions) using the following index for calculating CSR:

$$
\operatorname{CSRI}_{j}=\frac{\sum_{i=1}^{n} x_{i j}}{n_{j}}
$$

Where:

$\mathrm{CSRI}_{j}=$ Corporate social responsibility index of $j^{\text {th }}$ firm.

$n_{j}=$ Total number of CSR items for $j^{\text {th }}$ firm, $n=45$.

$X_{i j}=1$ if $i^{\text {th }}$ item is disclosed, 0 if the $i^{\text {th }}$ item is not disclosed.

So that $0 \leq \mathrm{CSRI}_{j} \leq 1$.

\section{Independent variables}

The institutional environment comprised formal institutions, such as legal, financial and political systems as well as informal institutions, such as cultural, values, norms and beliefs (Lubatkin et al. 2005). The nature of the political and legal system at the country level (Matten and Moon 2008) enables the prediction of a broader stakeholder orientation versus a more discrete shareholders' perspective.

The informal institutions exist in the form of cultural values, norms and have an omnipresent influence on "character of economies" in the form of normative or mimetic adoption of the practice (Scott 2008; Whitley 1992). For example, the lingering differences between New Zealand and Pakistan relating to the role of businesses in society are significant. New Zealand scores 79 on Hofstede's cultural dimension being a strongly individualistic society whereas Pakistan with a low score of 14 is considered as being highly collectivist. Similarly, Matten and Moon (2008) argued that the United States of America is a highly individualistic society with higher corporate discretion primarily manifest through philanthropic CSR, whereas European countries seek collaboration and consensus on CSR being more collectivist in nature. There is limited research available concerning the impact of Hofstede's dimensions on CSR practices. Fernandez-Feijoo et al. (2014) argued that companies which are located in more gender equal societies were found to employ more women on boards than that in gender unequal societies. But as argued in this research the informal institutions are expected to have a significant effect on managerial behaviour (Campbell 2007).

Hofstede's $(1984,1991)$ continua was used to incorporate the informal differences between New Zealand and Pakistan. The continua include uncertainty avoidance, power distance, individualism vs. collectivism, and masculinity vs. femininity. Hofstede found differences among employees of different origins at IBM. Ultimately, these differences translated into different organizational behaviours or the host country's external environment. The cultural dimensions have been previously used in comparative CSR studies (Bondy and Starkey 2014; Burton et al. 2000; Farooq et al. 2014). In addition, the variations in corporate regulation as mentioned above were identified from the annual report of the companies. However, for the current study these informal institutional environment variables, such as Hofstede's cultural dimensions and corruption perceptions index were not incorporated in the analysis.

\section{Results and discussions}

The companies and industries of the two country samples are presented in Tables 1 and 2 .

The descriptive statistics for the CSR disclosures including all five dimensions, such as environment, energy, employees, community, and customers oriented responsibilities are presented in Table 3. Levels of CSR disclosures do not appear to follow a specific logic. The sampled companies in Pakistan disclose more on environment-oriented responsibilities with a mean of .50 and std. deviation of .261 than those in New Zealand' mean of .3182 and std. deviation of .3182. The mean for disclosures on energy for companies in Pakistan is .4167 with std. deviation of 29547 and the mean for those in New Zealand is .250 with std. deviation of .35635. The mean for disclosures on employeeoriented responsibilities for companies in Pakistan is .5859 with std. deviation of .20027; and, surprisingly companies in New Zealand has the same score with std. deviation of .24307. Similarly, the mean of disclosures on community- 
Table 1 Sample companies from New Zealand

\begin{tabular}{lll}
\hline & Company Name & Industry \\
\hline 1 & Cavalier Corporation & Carpets \& textile \\
2 & Fletcher Building & Construction \\
3 & Freightways Ltd & Cargo airline \\
4 & Michael Hill International & Retailing \\
5 & Restaurant Brands & Restaurants \\
6 & Spark Telecom & Telecommunication \\
7 & ST Steel \& Tube & Metals \\
8 & Air New Zealand & Airline \\
\hline
\end{tabular}

oriented responsibilities for Pakistan is .71343 with std. deviation of .26452 and the mean for disclosures in New Zealand is .5893 with std. deviation .32788. The mean of disclosures for customer-oriented responsibilities in Pakistan was .6000 with std. deviation of .32071 and for New Zealand, the mean is .6750 with std. deviation .23755 . Finally, the overall CSR mean score for sampled Pakistani companies was .5634 with std. deviation of .20318 and that for sampled companies in New Zealand was .438 with std. deviation of .24598 .

These results demostrate that the sample Pakistani companies disclose more than those sample New Zealand companies. It might be the case that companies in economically advanced countries like New Zealand are neither required nor are mentioning broader stakeholders in their annual reports. If so, these results are similar to the previous studies, such as Dawkins and Ngunjiri (2008) and Waldman et al. (2006), both suggesting that companies in the developing world are more likely to disclose social concerns in their annual reports than companies in the developed world. Moreover, it is also clear from the analysis that the results of CSR disclosures in both the countries are different across different industries. This suggests that some sectors may report more CSR in their annual reports than others. Previous research suggests that businesses with more risk of environmental pollution disclose more information for their commitment to CSR

Table 2 Sample companies from Pakistan

\begin{tabular}{lll}
\hline \multicolumn{1}{c}{ Company Name } & Industry \\
\hline 1 Kohat Cement & Cement \\
2 Gul Ahmad Textile & Textile \\
3 Altern Energy & $\begin{array}{l}\text { Power generation \& } \\
\text { distribution }\end{array}$ \\
4 Engro fertiliser & Fertiliser \\
5 Crescent Steel and Allied Products & Engineering \\
Ltd & Pakistan Tobacco Company & Tobacco \\
7 Hino Pakistan & Automobile assembler \\
8 gsk & Pharmaceuticals \\
\hline
\end{tabular}

in the long run (Gamerschlag et al. 2011; Javaid Lone et al. 2016; Rayman-Bacchus et al. 2012). However, the results in Table 4 suggest there were no significant differences in disclosure practices of companies between New Zealand and Pakistan.

CSR reporting of selected Pakistani companies can be largely attributed to the institutional and regulatory environment. These informal institutions and regulatory measures are reflections of institutions for businesses to describe and monitor legitimacy (Dawkins and Ngunjiri 2008). As discussed above the regulatory structures in both the countries are near identical.

One explanation of this from an institutional perspective is provided by the practice of adoption (Gondo and Amis 2013). The frequency of a practice and level of legitimacy initially required a decrease by the actors involved in promoting the practice, as practice become implemented within the organization (Green 2004). This shows that CSR disclosure practices are important in the early stages of implementation and become less important as the practice becomes diffused and more substantive. This might be the case in Pakistan where CSR practices are at an early stage and businesses mostly use their annual reports to disclose CSR to get legitimacy (Ahmad et al. 2015). This suggests that businesses are not only subjected to scrutiny by government but also other interested stakeholders. Scholars in the field argue that businesses respond to institutional pressures and get social acceptance by adopting CSR practices (Amran and Haniffa 2011; Campbell 2007).

The informal institutional environment of each country apperas to play an important role in a company's decision to dislose within a context. Saxena and Mishra (2017) attributed the different perception of companies on CSR to Hofstede's cultural dimension. The ranking and score of New Zealand and Pakistan is provided in Table 5.

Table 5 demonstrates that the selected companies from Pakistan score high on power distance than those in New Zealand. Power distance refers to the extent to which unequal power distribution is accepted in institutions and organisations. That means that in Pakistan, normally lower ranked employees wait for instructions from top management, and that they do not have the authority to interfere or provide any sort of suggestions. This is evident from previous literature, as Islam (2004) corroborates that Pakistan is an autocratic society where the superior always makes the decisions in organisations and the sub-ordinates hardly have a say. In contrast, New Zealand's score on power distance is very low which means that elitism and superiority/hierarchy are disliked in the country. Moreover, it is evident that Pakistani society is collectivist in nature. In Pakistan, usually, the whole family depends on a single individual who takes care of everything and people normally take the responsibility of their group members (Islam 2004). 
Table 3 Descriptive statistics' from the analysis of Plc's in New Zealand and Pakistan (FYE 2016)

\begin{tabular}{|c|c|c|c|c|c|c|c|c|c|}
\hline & & \multirow[t]{2}{*}{ N } & \multirow[t]{2}{*}{ Mean } & \multirow{2}{*}{$\begin{array}{l}\text { Std. } \\
\text { Deviation }\end{array}$} & \multirow{2}{*}{$\begin{array}{l}\text { Std. } \\
\text { Error }\end{array}$} & \multicolumn{2}{|c|}{ 95\% Confidence Interval for Mean } & \multirow[t]{2}{*}{ Minimum } & \multirow[t]{2}{*}{ Maximum } \\
\hline & & & & & & Lower Bound & Upper Bound & & \\
\hline \multirow[t]{3}{*}{ Environment } & New Zealand & 8 & 0.3182 & 0.3035 & 0.1073 & 0.0645 & 0.5719 & 0.00 & 0.82 \\
\hline & Pakistan & 8 & 0.5000 & 0.2617 & 0.0925 & 0.2812 & 0.7188 & 0.09 & 0.82 \\
\hline & Total & 16 & 0.4091 & 0.2894 & 0.0724 & 0.2549 & 0.5633 & 0.00 & 0.82 \\
\hline \multirow[t]{3}{*}{ Energy } & New Zealand & 8 & 0.2500 & 0.3564 & 0.1260 & -0.0479 & 0.5479 & 0.00 & 0.83 \\
\hline & Pakistan & 8 & 0.4167 & 0.2955 & 0.1045 & 0.1696 & 0.6637 & 0.00 & 0.83 \\
\hline & Total & 16 & 0.3333 & 0.3277 & 0.0819 & 0.1587 & 0.5080 & 0.00 & 0.83 \\
\hline \multirow[t]{3}{*}{ Employees } & New Zealand & 8 & 0.5859 & 0.2431 & 0.0859 & 0.3827 & 0.7891 & 0.19 & 0.88 \\
\hline & Pakistan & 8 & 0.5859 & 0.2003 & 0.0708 & 0.4185 & 0.7534 & 0.31 & 0.94 \\
\hline & Total & 16 & 0.5859 & 0.2152 & 0.0538 & 0.4713 & 0.7006 & 0.19 & 0.94 \\
\hline \multirow[t]{3}{*}{ Community } & New Zealand & 8 & 0.5893 & 0.3279 & 0.1159 & 0.3152 & 0.8634 & 0.00 & 0.86 \\
\hline & Pakistan & 8 & 0.7143 & 0.2645 & 0.0935 & 0.4931 & 0.9354 & 0.29 & 1.00 \\
\hline & Total & 16 & 0.6518 & 0.2949 & 0.0737 & 0.4946 & 0.8089 & 0.00 & 1.00 \\
\hline \multirow[t]{3}{*}{ Customers } & New Zealand & 8 & 0.6750 & 0.2376 & 0.0840 & 0.4764 & 0.8736 & 0.40 & 1.00 \\
\hline & Pakistan & 8 & 0.6000 & 0.3207 & 0.1134 & 0.3319 & 0.8681 & 0.00 & 1.00 \\
\hline & Total & 16 & 0.6375 & 0.2754 & 0.0688 & 0.4908 & 0.7842 & 0.00 & 1.00 \\
\hline \multirow[t]{3}{*}{ Overall CSR } & New Zealand & 8 & 0.4837 & 0.2460 & 0.0870 & 0.2780 & 0.6893 & 0.12 & 0.85 \\
\hline & Pakistan & 8 & 0.5634 & 0.2032 & 0.0718 & 0.3935 & 0.7332 & 0.18 & 0.81 \\
\hline & Total & 16 & 0.5235 & 0.2218 & 0.0555 & 0.4053 & 0.6417 & 0.12 & 0.85 \\
\hline
\end{tabular}

Collectivism transforms to businesses as well where the selection of an employee to an retrenchment process is likely to involve group decision making. On the other hand, New Zealand is a strong individualistic society. The hiring and laying off processes are done on merit. Thirdly, Pakistan has medium scores on masculinity/femininity which means masculinity/femininity cannot be segregated (Hofstede et al. 2010). This is due to significant growth of middle-class families, increase in education, a rich national identity, and enhanced global awareness in the country (Salman 2015). On the contrary, New Zealand is considered to be a masculine country because of the significantly high score on this dimension (Hofstede et al. 2010). Countries with the varying score on masculinity ranking tend to allocate roles of males and female differently within organizations (Hamid 2017). Finally, Pakistan has a relatively higher score on uncertainty avoidance than New Zealand. A country with a low score on this dimension tends to welcome risk and changes, whereas countries with a higher score on uncertainty avoidance respect rules and regulations (Hofstede and Hofstede 2003). Respecting the government regulation is apparent in Pakistan, although it may only be in form, not substance. This result is evident in the higher degree of CSR disclosures in Pakistan as a result of SECP guidelines (Javaid Lone et al. 2016).

In addition to Hofstede et al.'s (2010) cultural dimensions, Khan (2007) contended that Pakistan has gone through extremely debilitating and entrenched corruption that resulted in the government's inability to provide services and maintain law and order in the country. According to Islam (2004), corruption in Pakistan is due to adherence to the hierarchy and the collective administrative culture. Warf (2016) attributes corruption to deeply embedded cultural and moral values and not simply an economic phenomenon. This is the primary reason why Transparency International (2017) ranked Pakistan 116 out of 176. However, New Zealand is considered as the world least corrupt country with a score of 96 and ranked 1 st out of 176. Pakistan has slightly improved on this corruption index but practical measures need to be taken. Corruption is rampant in Pakistan and being a few points up and down on the international corruption scale will not help Pakistan change the reality (Malik 2017).

The above mentioned institutional factors help explain the large variations in CSR disclosures. The findings of the current study are consistent with earlier work (Dawkins and Ngunjiri 2008; Hoffman 1999; Sharfman et al. 2004), despite the small sample CSR is observed to be affected by regional-specific institutional pressures. These pressures might involve respecting the guidelines from regulators, and the pressures to respect the preferences of a particular group of stakeholders. As according to the institutional theory businesses have three different types of pressures, such as coercive pressures in the form of regulation; normative pressures in the form of values and culture; and, mimetic pressures in the form of mimicking the behaviour 
Table 4 ANOVA results for the analysis of PIc's in New Zealand and Pakistan (FYE 2016)

\begin{tabular}{|c|c|c|c|c|c|c|}
\hline & & $\begin{array}{l}\text { Sum of } \\
\text { Squares }\end{array}$ & Df & $\begin{array}{l}\text { Mean } \\
\text { Square }\end{array}$ & $\mathrm{F}$ & Sig. \\
\hline \multirow[t]{3}{*}{ Environment } & Between Groups & 0.132 & 1 & 0.132 & 1.647 & 0.22 \\
\hline & Within Groups & 1.124 & 14 & 0.08 & & \\
\hline & Total & 1.256 & 15 & & & \\
\hline \multirow[t]{3}{*}{ Energy } & Between Groups & 0.111 & 1 & 0.111 & 1.037 & 0.326 \\
\hline & Within Groups & 1.5 & 14 & 0.107 & & \\
\hline & Total & 1.611 & 15 & & & \\
\hline \multirow[t]{3}{*}{ Employees } & Between Groups & 0 & 1 & 0 & 0 & 1 \\
\hline & Within Groups & 0.694 & 14 & 0.05 & & \\
\hline & Total & 0.694 & 15 & & & \\
\hline \multirow[t]{3}{*}{ Community } & Between Groups & 0.063 & 1 & 0.063 & 0.704 & 0.415 \\
\hline & Within Groups & 1.242 & 14 & 0.089 & & \\
\hline & Total & 1.305 & 15 & & & \\
\hline \multirow[t]{3}{*}{ Customers } & Between Groups & 0.022 & 1 & 0.022 & 0.283 & 0.603 \\
\hline & Within Groups & 1.115 & 14 & 0.08 & & \\
\hline & Total & 1.138 & 15 & & & \\
\hline \multirow[t]{3}{*}{ CSR } & Between Groups & 0.025 & 1 & 0.025 & 0.499 & 0.491 \\
\hline & Within Groups & 0.713 & 14 & 0.051 & & \\
\hline & Total & 0.738 & 15 & & & \\
\hline
\end{tabular}

of other companies especially in a scenario characterised by uncertainty and rapid change.

\section{Conclusion}

The main objective of this paper was to identify and understand the plausible explanation for CSR reporting in New Zealand and Pakistan. The study included a quantitative content analysis of annual reports of a select sample of listed companies and proceeded with ANOVA measuring the variability of CSR disclosure between the two jurisdictions. The results of ANOVA were not significant. Institutional theory was use to explain the process of CSR disclosures and identify the contextual factors for each country. As Kolk (2005) argued, CSR is observed to be shaped quite differently in different countries because of the respective different institutional environments. The study explained some of these institutional factors in detail. The study found that the sample of overall Pakistani

Table 5 Hofstede's Cultural Dimensions of Pakistan and New Zealand

\begin{tabular}{lll}
\hline Cultural Dimensions & Pakistan & New Zealand \\
\hline Power Distance & 55 & 22 \\
Individualism & 14 & 79 \\
Masculinity & 50 & 58 \\
Uncertainty Avoidance & 70 & 49 \\
\hline
\end{tabular}

Source: (Hofstede et al. 2010) companies disclose more than those in New Zealand on the five dimensions of CSR. Other recently conducted research concluded that the increase in the level of CSR disclosures in Pakistan is attributed to SECP's corporate governance guidelines 2013 (Javaid Lone et al. 2016). Hofstede et al.'s (2010) work highlighted the major differences between countries in terms of power distance, individualism, masculinity and uncertainty avoidance. These differences appear to transform businesses and its affect CSR disclosure practices (Dawkins and Ngunjiri 2008). The findings of the study are in line with the three forms of isomorphism, coercive, normative and mimetic do contribute to CSR reporting in New Zealand and Pakistan. Additionally, the results demonstrate that the disclosure practices also varied across the different sectors within both the countries. The highly polluting industries, such as cement were found to disclose the most. That suggests that a high impact industry might report more compare to relatively low impact industries, such as retailing.

\section{Limitations}

The results for the current study need to be interpreted with caution, bearing in mind the limitations of the study. To start with the annual reports of the companies analysed for the current study comprised a small select sample from both the countries which may not be representative of the whole population. Therefore, studies with a simple random sample may provide more reliable results. Additionally, longitudinal studies will identify changes to CSR disclosures and could reveal other dimensions.

Secondly, the study is based on quantitative content analysis which is subject to human error. The study has not included qualitative analysis. Qualitative content analysis might provide better and an in-depth understanding of the reasons behind CSR reporting.

Finally, Baskerville (2003) argued that there are certain limitations to utilising Hofstede's cultural indices, such as understanding culture by means of metrics and numeric measures and the assumption of equating nations with cultures. Therefore, apart from Hofstede cultural dimensions and corruption index, there are likely to be the other factors that need to be considered while assessing the effect on CSR (Thanetsunthorn 2014). These factors might contribute to a lack of transparency and accountability which is prevalent in all levels of Pakistani society, and only on very rare occasions emerge in New Zealand, for example, the collapse of finance companies in the aftermath of the global financial crises. Healthcare and education systems in Pakistan are in a troublesome situation, with quarter of population undernourished and women's literacy is less than $35 \%$. Therefore, there is a marked difference between both countries in terms of informal institutional infrastructure beyond Hofstede's cultural dimensions. 


\section{Abbreviations}

ANOVA: Analysis of Variance; CA: Companies Act; CSR: Corporate Social Responsibility; FMA: Financial Market Authority; FRA: Financial Reporting Act; gsk: GlaxoSmithKline; KPMG: Klynveld Peat Marwick Goerdeler; NZSX: New Zealand Stock Exchange; OECD: Organization of Economic Cooperation and Development; PSX: Pakistan Stock Exchange; SECP: Securities and Exchange Commission of Pakistan; SPSS: Statistical Package for the Social Sciences

\section{Acknowledgements}

Not applicable.

\section{Funding}

The author received financial support for the research, authorship, and/or publication of this article from the Higher Education Commission Pakistan.

\section{Availability of data and materials}

The data for quantitative analysis for the selected sample were collected from the publicly available annual reports of the listed companies from New Zealand and Pakistan. The SPSS datasheet will be available upon request from the corresponding author.

\section{Authors' contributions}

All authors contributed equally to this research. All authors read and approved the final manuscript.

\section{Competing interests}

The authors declare that they have no competing interests.

\section{Publisher's Note}

Springer Nature remains neutral with regard to jurisdictional claims in published maps and institutional affiliations.

\section{Received: 30 October 2017 Accepted: 30 January 2018}

\section{Published online: 26 February 2018}

\section{References}

Aquinis, H., \& Glavas, A. (2012). What we know and don't know about corporate social responsibility: A review and research agenda. Journal of Management, 38(4), 932-968. https://doi.org/10.1177/0149206311436079.

Ahmad, N., Taiba, S., Kazmi, S. M. A., \& Ali, H. N. (2015). Concept and elements of corporate social responsibility (CSR) and its Islamic perspective: Mainstream business management concern in Pakistan. Pakistan Journal of Social Sciences, 35(2), 925-934

Ahmad, S. J. (2006). From principles to practice. Journal of Corporate Citizenship, 24(15), 115-129.

Ahmed, A. \& Ahmed, I. (2011). Corporate conscience CSR in Pakistan - a study. Bangalore: Sustainable Development Policy Institute (SDPI).

Ahmed Haji, A. (2013). Corporate social responsibility disclosures over time: Evidence from Malaysia. Managerial Auditing Journal, 28(7), 647-676.

Amran, A., \& Haniffa, R. (2011). Evidence in development of sustainability reporting: A case of a developing country. Business Strategy and the Environment, 20(3), 141-156.

Aras, G., Aybars, A., \& Kutlu, O. (2010). Managing corporate performance: Investigating the relationship between corporate social responsibility and financial performance in emerging markets. International Journal of Productivity and Performance Management, 59(3), 229-254.

Ashraf, S. (2018). CSR in Pakistan: The case of the Khaadi controversy. In G. Grigore, A. Stancu, \& D. McQueen (Eds.), Corporate responsibility and digital communities: An international perspective towards sustainability (pp. 247-269). Cham: Springer International Publishing.

Bachmann, P., \& Ingenhoff, D. (2016). Legitimacy through CSR disclosures? The advantage outweighs the disadvantages. Public Relations Review, 42(3), 386-394

Baldwin, R. (2004). The new punitive regulation. The Modern Law Review, $67(3), 351-383$

Bartle, I., \& Vass, P. (2007). Self-regulation within the regulatory state: Towards a new regulatory paradigm? Public Administration, 85(4), 885-905.

Baskerville, R. F. (2003). Hofstede never studied culture. Accounting, Organizations and Society, 28(1), 1-14.
Baumann-Pauly, D., Wickert, C., Spence, L. J., \& Scherer, A. G. (2013). Organizing corporate social responsibility in small and large firms: Size matters. Journal of Business Ethics, 115(4), 693-705.

Belal, A. R., \& Momin, M. (2009). Corporate social reporting (CSR) in emerging economies: A review and future direction. Research in Accounting in Emerging Economies, 9(1), 119-143.

Berger, P. L., \& Luckmann, T. (1966). The social construction of reality: A treatise in the sociology of knowledge. New York: First Anchor.

Birkey, R. N., Guidry, R. P., Islam, M. A., \& Patten, D. M. (2016). Mandated social disclosure: An analysis of the response to the California Transparency in Supply Chains Act of 2010. Journal of Business Ethics, (In press, 1-15.

Birkey, R. N., Michelon, G., Patten, D. M., \& Sankara, J. (2016). Does assurance on CSR reporting enhance environmental reputation? An examination in the US context. Paper presented at the Accounting Forum.

Black, J. (1996). Constitutionalising self-regulation. The Modern Law Review, $59(1), 24-55$.

Blackmore, J. (2006). Evaluating New Zealand's evolving corporate governance regulatory regime in a comparative context. Canterbury Law Review, 12, 34.

Bondy, K., \& Starkey, K. (2014). The dilemmas of internationalization: Corporate social responsibility in the multinational corporation. British Journal of Management, 25(1), 4-22.

Brammer, S., Jackson, G., \& Matten, D. (2012). Corporate social responsibility and institutional theory: New perspectives on private governance. Socio-Economic Review, 10(1), 3-28.

Burton, B. K., Farh, J.-L., \& Hegarty, W. H. (2000). A cross-cultural comparison of corporate social responsibility orientation: Hong Kong vs. United States students. Teaching Business Ethics, 4(2), 151-167.

Campbell, D. J. (2000). Legitimacy theory or managerial reality construction? Corporate social disclosure in marks and Spencer plc corporate reports, 19691997. Paper presented at the Accounting forum, Blackwell Publishers Ltd.

Campbell, J. L. (2007). Why would corporations behave in socially responsible ways? An institutional theory of corporate social responsibility. The Academy of Management Review, 32(3), 946-967.

Carpenter, V. L., \& Feroz, E. H. (2001). Institutional theory and accounting rule choice: An analysis of four US state governments' decisions to adopt generally accepted accounting principles. Accounting, Organizations and Society, 26(7), 565-596.

Carroll, A. B. (2008). A history of corporate social responsibility. In A. Crane, A. McWilliams, D. Matten, J. Moon, \& D. Siegel (Eds.), The Oxford handbook of corporate social responsibility (pp. 19-46). Oxford: Oxford University Press.

Chauvey, J.-N., Giordano-Spring, S., Cho, C. H., \& Patten, D. M. (2015). The normativity and legitimacy of CSR disclosure: Evidence from France. Journal of Business Ethics, 130(4), 789-803.

Cochran, P. L., \& Wood, R. A. (1984). Corporate social responsibility and financial performance. The Academy of Management Journal, 27(1), 42-56.

Collins, E., Roper, J., \& Lawrence, S. (2010). Sustainability practices: Trends in New Zealand businesses. Business Strategy and the Environment, 19(8), 479-494.

Dawkins, C., \& Ngunjiri, F. W. (2008). Corporate social responsibility reporting in South Africa: A descriptive and comparative analysis. The Journal of Business Communication, 45(3), 286-307.

De Bakker, F. G., Groenewegen, P., \& Den Hond, F. (2005). A bibliometric analysis of 30 years of research and theory on corporate social responsibility and corporate social performance. Business \& Society, 44(3), 283-317.

Deegan, C., \& Unerman, J. (2009). Financial accounting theory. Australia: McGraw-Hill.

Delaney, A., Burchielli, R., \& Tate, J. (2016). Corporate CSR responses to homework and child labour in the Indian and Pakistan leather sector. In K. Grosser, L. McCarthy, \& M. Kilmore (Eds.), Can CSR responses be inclusive of informal women worker rights and priorities? Greenleaf: Leeds.

Diehl, S., Terlutter, R., \& Mueller, B. (2016). Doing good matters to consumers: The effectiveness of humane-oriented CSR appeals in cross-cultural standardized advertising campaigns. International Journal of Advertising, 35(4), 730-757.

DiMaggio, P., \& Powell, W. W. (1983). The iron cage revisited: Collective rationality and institutional isomorphism in organizational fields. American Sociological Review, 48(2), 147-160.

DiMaggio, P. J., \& Powell, W. W. (1991). The new institutionalism in organizational analysis (Vol. 17). Chicago: University of Chicago Press.

Doane, M. A. (2002). The emergence of cinematic time: Modernity, contingency, the archive. Cambridge: Harvard University Press.

Dobbs, S, \& van Staden, C. (2016). Motivations for corporate social and environmental reporting: New Zealand evidence. Sustainability 
Accounting, Management and Policy Journal, 7(3), 449-472 https://doi.org/ 10.1108/SAMPJ-08-2015-0070.

Doh, J. P., \& Guay, T. R. (2006). Corporate social responsibility, public policy, and NGO activism in Europe and the United States: An institutional-stakeholder perspective. Journal of Management Studies, 43(1), 47-73.

Eccles, R. G., \& Krzus, M. P. (2010). One report: Integrated reporting for a sustainable strategy. New Jersey: Wiley.

Eweje, G., \& Bentley, T. (2006). CSR and staff retention in New Zealand companies: A literature review, Department of Management and International Business Research Working Paper Series, no. 6. Auckland: Massey University.

Farooq, O., Payaud, M., Merunka, D., \& Valette-Florence, P. (2014). The impact of corporate social responsibility on organizational commitment: Exploring multiple mediation mechanisms. Journal of Business Ethics, 125(4), 563-580.

Fernandez-Feijoo, B., Romero, S., \& Ruiz-Blanco, S. (2014). Women on boards: Do they affect sustainability reporting? Corporate Social Responsibility and Environmental Management, 21(6), 351-364

Fernando, S. J. (2013). Corporate social responsibility practices in a developing country: Empirical evidence from Sri Lanka, Doctoral dissertation. Hamilton: The University of Waikato Retrieved from http://researchcommons.waikato.ac.nz.

Fifka, M. S. (2013). Corporate responsibility reporting and its determinants in comparative perspective-a review of the empirical literature and a metaanalysis. Business Strategy and the Environment, 22(1), 1-35.

Frame, B., Gordon, R., \& Whitehouse, I. (2003). Corporate responsibility on New Zealand - a case study. Lincoln: Landcare Research NZ Ltd.

Gamerschlag, R., Möller, K., \& Verbeeten, F. (2011). Determinants of voluntary CSR disclosure: Empirical evidence from Germany. Review of Managerial Science, 5(2-3), 233-262.

Garcia-Sanchez, I.-M., Cuadrado-Ballesteros, B., \& Frias-Aceituno, J.-V. (2016). Impact of the institutional macro context on the voluntary disclosure of CSR information. Long Range Planning, 49(1), 15-35. https://doi.org/10.1016/j.lrp.2015.02.004.

Gjølberg, M. (2009). The origin of corporate social responsibility: Global forces or national legacies? Socio-Economic Review, 7(4), 605-637.

Golob, U., \& Bartlett, J. L. (2007). Communicating about corporate social responsibility: A comparative study of CSR reporting in Australia and Slovenia. Public Relations Review, 33(1), 1-9.

Gondo, M. B., \& Amis, J. M. (2013). Variations in practice adoption: The roles of conscious reflection and discourse. The Academy of Management Review, 38(2), 229-247.

Gray, R., Kouhy, R., \& Lavers, S. (1995). Corporate social and environmenta reporting: A review of the literature and a longitudinal study of UK disclosure. Accounting, Auditing \& Accountability Journal, 8(2), 47-77.

Green, S. E. (2004). A rhetorical theory of diffusion. The Academy of Management Review, 29(4), 653-669.

Grunig, J. E. (1989). Excellence in public relations and communication management. London: Routledge.

Hackston, D., \& Milne, M. J. (1996). Some determinants of social and environmental disclosures in New Zealand companies. Accounting, Auditing and Accountability Journal, 9(1), 77-108.

Hamid, M. A. (2017). Analysis of visual presentation of cultural dimensions: Culture demonstrated by pictures on homepages of universities in Pakistan. Journal of Marketing Communications, 23(6), 1-22.

Haniffa, R. M., \& Cooke, T. E. (2005). The impact of culture and governance on corporate social reporting. Journal of Accounting and Public Policy, 24(5), 391-430.

Hassan, M. T., Kausar, A., Ashiq, H., Inam, H., Nasar, H., Amjad, R., \& Lodhi, M. A. (2012). Corporate social responsibility disclosure: A comparison between Islamic and conventional financial institutions in Bahawalpur region. International Journal of Learning and Development, 2(1), 628-642.

Hoffman, A. J. (1999). Institutional evolution and change: Environmentalism and the US chemical industry. The Academy of Management Journal, 42(4), 351-371.

Hofstede, G. H. (1984). Culture's consequences: International differences in workrelated values (Vol. 5). London: Sage Publications.

Hofstede, G. H., \& Hofstede, G. J. (2003). Culture's consequences: Comparing values, behaviors, institutions and organizations across nations. London: Sage Publications.

Hofstede, G. H., Hofstede, G. J., \& Minkov, M. (2010). Cultures and organizations: Software of the mind: Intercultural cooperation and its importance for survival (3rd ed.). New York: McGraw-Hill.

Hooghiemstra, R. (2000). Corporate communication and impression management-new perspectives why companies engage in corporate social reporting. Journal of Business Ethics, 27(1), 55-68.
Hull, C. E., \& Rothenberg, S. (2008). Firm performance: The interactions of corporate social performance with innovation and industry differentiation. Strategic Management Journal, 29(7), 781-789.

Hutter, B. M. (2001). Regulation and risk: Occupational health and safety on the railways. Oxford: Oxford University Press on Demand.

Islam, N. (2004). Sifarish, sycophants, power and collectivism: Administrative culture in Pakistan. International Review of Administrative Sciences, 70(2), 311-330.

Jabeen, H., \& Khan, F. N. (2008). Philanthropy: Trends and approaches a case study of Karachi. Journal of Independent Studies and Research (JISR), 6(1), 31-35.

Jackson, G., \& Apostolakou, A. (2010). Corporate social responsibility in Western Europe: An institutional mirror or substitute? Journal of Business Ethics, 94(3), 371-394.

Javaid Lone, E., Javaid Lone, E., Ali, A., Ali, A., Khan, I., \& Khan, I. (2016). Corporate governance and corporate social responsibility disclosure: Evidence from Pakistan. The International Journal of Business in Society, 16(5), 785-797.

Javid, A. Y., \& lqbal, R. (2010). Corporate governance in Pakistan: Corporate valuation, ownership and financing, Working Papers \& Research Reports, 2010. Islamabad: Pakistan Institute of Development Economics.

Jitaree, W. (2015). Corporate social responsibility disclosure and financial performance: Evidence from Thailand, Doctor of philosophy. New South Wales: University of Wollongong.

Jo, H., \& Na, H. (2012). Does CSR reduce firm risk? Evidence from controversial industry sectors. Journal of Business Ethics, 110(4), 441-456.

Kang, N., \& Moon, J. (2011). Institutional complementarity between corporate governance and corporate social responsibility: A comparative institutional analysis of three capitalisms. Socio-Economic Review, 10(1), 85-108.

Karam, C. M., \& Jamali, D. (2017). A cross-cultural and feminist perspective on CSR in developing countries: Uncovering latent power dynamics. Journal of Business Ethics, 142(3), 461-477. https://doi.org/10.1007/s10551-015-2737-7.

Kelsey, J. (1995). The New Zealand experiment. Auckland: Auckland University Press.

Khan, F. (2007). Corruption and the decline of the state in Pakistan. Asian Journal of Political Science, 15(2), 219-247.

Kolk, A. (2005). Environmental reporting by multinationals from the triad: Convergence or divergence? MIR: Management International Review, 45(1), 145-166.

Lenssen, G., Blagov, Y., Bevan, D., Vurro, C., \& Perrini, F. (2011). Making the most of corporate social responsibility reporting: Disclosure structure and its impact on performance. The International Journal of Business in Society, 11(4), 459-474.

Lubatkin, M. H., Lane, P. J., Collin, S.-O., \& Very, P. (2005). Origins of corporate governance in the USA, Sweden and France. Organization Studies, 26(6), 867-888.

Luo, X., \& Bhattacharya, C. B. (2009). The debate over doing good: Corporate social performance, strategic marketing levers, and firm-idiosyncratic risk. Journal of Marketing, 73(6), 198-213.

Malik, T. H. (2017). Corrupt culture. Retrieved from https://www.dawn.com/news/ 1315014/corrupt-culture.

Margolis, J. D., \& Walsh, J. P. (2003). Misery loves companies: Rethinking social initiatives by business. Administrative Science Quarterly, 48(2), 268-305.

Matten, D., \& Moon, J. (2008). "Implicit" and "explicit" CSR: A conceptual framework for a comparative understanding of corporate social responsibility. The Academy of Management Review, 33(2), 404-424.

Milne, M. J., \& Adler, R. W. (1999). Exploring the reliability of social and environmental disclosures content analysis. Accounting, Auditing \& Accountability Journal, 12(2), 237-256.

Ministry of Business Innovation and Employment. (1993). Companies Act. Retrieved from http:/www.legislation.govt.nz/act/public/1993/0105/latest/DLM319570.html.

Moll, J., Burns, J., \& Major, M. (2006). Institutional theory. In Hoque, Z. (Ed.), Methodological issues in accounting research: Theories, methods and issues (pp. 183-205). London: Spiramus Press.

Nakpodia, F., Adegbite, E., Amaeshi, K., \& Owolabi, A. (2016). Neither Principles Nor Rules: Making Corporate Governance Work in Sub-Saharan Africa. Journal of Business Ethics. https://doi.org/10.1007/s10551-016-3208-5.

Nazli Nik Ahmad, N., \& Sulaiman, M. (2004). Environment disclosure in Malaysia annual reports: A legitimacy theory perspective. International Journal of Commerce and Management, 14(1), 44-58.

Palzer, C., \& Scheuer, A. (2003). Self-regulation, co-regulation, public regulation. Promote or Protect, 165.

Parker, L. (2014). Constructing a research field: A reflection on the history of social and environmental accounting. Social and Environmental Accountability Journal, 34(2), 87-92.

Platonova, E., Asutay, M., Dixon, R.. \& Mohammad, S. (2016). The impact of corporate social responsibility disclosure on financial performance: Evidence 
from the GCC Islamic banking sector. Journal of Business Ethics, 1-21. https:// doi.org/10.1007/s10551-016-3229-0.

Qiu, Y., Shaukat, A., \& Tharyan, R. (2016). Environmental and social disclosures: Link with corporate financial performance. The British Accounting Review, 48(1), 102-116.

Rahim, M. M. (2013). Legal regulation of corporate social responsibility: A metaregulation approach of law for raising CSR in a weak economy. Heidelberg: Springer Science \& Business Media

Rayman-Bacchus, L., Husser, J., André, J.-M., Barbat, G., \& Lespinet-Najib, V. (2012). CSR and sustainable development: Are the concepts compatible? Management of Environmental Quality: An International Journal, 23(6), 658-672.

Raza, J., \& Majid, A. (2016). Perceptions and practices of corporate social responsibility among SMEs in Pakistan. Quality \& Quantity, 50(6), 2625-2650.

Reddy, K., Locke, S., \& Scrimgeour, F. (2010). The efficacy of principle-based corporate governance practices and firm financial performance. International Journal of Managerial Finance, 6(3), 190-219. https://doi.org/10.1108/17439131011056224.

Roper, J. (2004). Corporate social responsibility in New Zealand. Journal of Corporate Citizenship, 14(Summer), 22-25.

Sajjad, A., \& Eweje, G. (2014). Corporate social responsibility in Pakistan: Current trends and future directions. In W. Sun (Ed.), Corporate social responsibility and sustainability: Emerging trends in developing economies (pp. 163-187). Warrington: Emerald Group Publishing Limited.

Salman, M. (2015). Hofstede dimensions of culture: A brief comparison of Pakistan and New Zealand. Academy of Comtemporary Research Journal, 4(3), 22-26.

Saxena, M., \& Mishra, D. K. (2017). CSR perception: A global opportunity in management education. Industrial and Commercial Training, 49(5), 231-244.

Scott, W. R. (2008). Approaching adulthood: The maturing of institutional theory. Theory and Society, 37(5), 427-442.

Securities and Exchange Commission of Pakistan. (2013). Corporate social responsibility voluntary guideline 2013. Islamabad: SECP.

Securities and Exchange Commission of Pakistan. (2017). Listed companies (code of corporate governance) regulations, 2017. Islamabad: SECP.

Shahid, K. K. (2012). Corporate social responsibility in Pakistan. Pakistan Today Retrieved from https://www.pakistantoday.com.pk/2012/01/15/corporatesocial-responsibility-in-pakistan/. Accessed 15 Nov 2017.

Sharfman, M. P., Shaft, T. M., \& Tihanyi, L. (2004). A model of the global and institutional antecedents of high-level corporate environmental performance. Business \& Society, 43(1), 6-36.

Spitzeck, H. (2009). The development of governance structures for corporate responsibility. The International Journal of Business in Society, 9(4), 495-505. https://doi.org/10.1108/14720700910985034.

Streeck, W., \& Thelen, K. (2005). Introduction: Institutional change in advanced political economies. In W. Streeck \& K. Thelen (Eds.), Beyond continuity: Institutional change in advanced political economies. Oxford: Oxford University Press.

Sweeney, L. (2009). A study of current practice of corporate social responsibility (CSR) and an examination of the relationship between CSR and financial performance using structural equation modelling (SEM), Unpublished doctoral thesis. Ireland: Dublin Institute of Technology.

Tahir, S. H., Muhammad, H. M. S. A. A., \& ul Haq, A. (2012). Two-tier corporate governance model for Pakistan. European Journal of Business and Management, 4(6), 38-48.

Tempel, A., \& Walgenbach, P. (2007). Global standardization of organizational forms and management practices? What new institutionalism and the business-systems approach can learn from each other. Journal of Management Studies, 44(1), 1-24.

Thanetsunthorn, N. (2014). Ethical organization: The effects of national culture on CSR. Organization Development Journal, 32(3), 89-109.

Tilt, C. A. (2001). The content and disclosure of Australian corporate environmental policies. Accounting, Auditing \& Accountability Journal, 14(2), 190-212.

Transparency International. (2017). Corruption perceptions index 2016 Retrieved from https://www.transparency.org/news/feature/corruption perceptions_index_2016.

Tschopp, D., \& Huefner, R. J. (2015). Comparing the evolution of CSR reporting to that of financial reporting. Journal of Business Ethics, 127(3), 565-577.

Udayasankar, K. (2008). Corporate social responsibility and firm size. Journal of Business Ethics, 83(2), 167-175.

Unerman, J. (2008). Strategic reputation risk management and corporate social responsibility reporting. Accounting. Auditing \& Accountability Journal, 21(3), 362-364.

Unerman, J., \& Bennett, M. (2004). Increased stakeholder dialogue and the internet: Towards greater corporate accountability or reinforcing capitalist hegemony? Accounting. Organizations and Society, 29(7), 685-707. van der Laan, S. (2009). The role of theory in explaining motivation for corporate social disclosures: Voluntary disclosures vs 'solicited' disclosures. Australasian Accounting Business \& Finance Journal, 3(4), 123-151.

Visser, W., \& Tolhurst, N. (2010). The world quide to CSR: A country-by-country analysis of corporate sustainability and responsibility. Sheffield: Greenleaf Publishing.

Waheed, A. (2005). Corporate social responsibility in Pakistan and a strategy for implementation. Securities and exchange Commission of Pakistan. Responsible business initiative. Retrieved from https://www.grli.org/wpcontent/uploads/2015/09/ambreen_rbi-_csr_perspective_from_pakistan.pdf.

Waldman, D. A., De Luque, M. S., Washburn, N., House, R. J., Adetoun, B., Barrasa, A., et al. (2006). Cultural and leadership predictors of corporate social responsibility values of top management: A GLOBE study of 15 countries. Journal of International Business Studies, 37(6), 823-837.

Warf, B. (2016). Global geographies of corruption. Geo Journal, 81(5), 657-669.

Warriach, F. A. (2017). Pakistan has World's 6th largest population in the nation. Retrieved from http://nation.com.pk/newspaper-picks/06-Jan-2017/pakistanhas-world-s-6th-largest-population.

Whitley, R. (1992). European business systems: Firms and markets in their national contexts. London: Sage.

Xiaowei Rose, L. U. O., Danqing, W., \& Jianjun, Z. (2017). Whose call to answer: Institutional complexity and firms' CSR reporting. The Academy of Management Journal, 60(1), 321-344. https://doi.org/10.5465/amj.2014.0847.

Zeghal, D., \& Ahmed, S. A. (1990). Comparison of social responsibility information disclosure media used by Canadian firms. Accounting, Auditing \& Accountability Journal, 3(1), 38-53.

\section{Submit your manuscript to a SpringerOpen ${ }^{\circ}$ journal and benefit from:}

- Convenient online submission

- Rigorous peer review

- Open access: articles freely available online

- High visibility within the field

- Retaining the copyright to your article

Submit your next manuscript at $\gg$ springeropen.com 